\title{
Monitoring and Controlling of pH Levels and Plant Nutrition Supplied by Standalone Photovoltaic in a Greenhouse Hydroponic System using Arduino Uno
}

\author{
Lutfi Athanuzul Kurniawan ${ }^{1)}$ and Amirullah ${ }^{2 *)}$ \\ ${ }^{1,2)}$ Electrical Engineering Study Program, Universitas Bhayangkara Surabaya, Indonesia \\ Corresponding Email: *) amirullah@ubhara.ac.id
}

\begin{abstract}
This paper aims to implement the prototype model to monitor and control the $\mathrm{pH}$ levels and nutrition plant (electrical conductivity-EC) supplied by a standalone photovoltaic (PV) module-connected battery (Lithium-Ion) on the greenhouse hydroponic systems. The pH and EC sensors are connected to the Arduino Uno circuit as a relay control to drive four pumps, i.e. the water flow pump, EC pump, $\mathrm{pH}$ up pump, and $\mathrm{pH}$ down pump. The greenhouse function to control pests and the impact of environmental non-uniformity caused by variation of wind speed, temperature, or sunlight so that hydroponic plants can grow in an appropriate environment. The Arduino Uno circuit with a $20 \times 4$ liquid crystal display (LCD) order four relays to monitor and control the four pumps of the greenhouse hydroponic system based on the coding which has been programmed previously. The prototype model is able to monitor and control the $\mathrm{pH}$ of hydroponic plant water at the level between 6-7 using a pH-up and pH-down sensor. This model is also able to monitor and control nutrition plant water over $1 \mathrm{mS} / \mathrm{cm}$ using an EC sensor. Finally, the proposed prototype is able to monitor and control EC and pH level to regulate plant growth in the greenhouse hydroponic system normally and in real-time.
\end{abstract}

Keywords: Standalone PV, pH, EC, Greenhouse, Hydroponic, Arduino Uno

\section{INTRODUCTION}

Recently, hydroponics has become a new method of cultivating plants, especially various types of vegetables or fruit, because they do not require large areas of land and can be done in the yard of the house. The hydroponic method uses a solution of mineral nutrients and water without using soil media for the process of growing and maintaining plants. Hydroponic cultivation in greenhouses is now an option to overcome the constraints of cultivating plants in open areas i.e. attack by pests, wind, temperature, and sunlight which sometimes also interfere with the growth and development of vegetable or fruit plants.

The PV module is a source of electrical power to operate the $\mathrm{pH}$ control system and the water level of hydroponic plant nutrients until the harvest period has been implemented in [1]. The proposed prototype was able to control the water $\mathrm{pH}$ level of 6-7 and the nutrition solution height of $18-20 \mathrm{~cm}$. This model works when the $\mathrm{pH}$ sensor detects below 6 then the solenoid valve at $\mathrm{pH}$ up automatically opens and flows into the nutrition solution. Thus, when the sensor detects a $\mathrm{pH}$ of more than 7 , the solenoid valve will open and the $\mathrm{pH}$-down solution will flow into the nutrition solution. The solenoid valve will close again when the sensor detects the $\mathrm{pH}$ in the range of 6-7. The water level control works when the ultrasonic sensor detects a value of $18 \mathrm{~cm}$, the solenoid valve will open and the nutrition water flows into the nutrition bath, otherwise, the solenoid valve closes again when the sensor detects a value of $20 \mathrm{~cm}$. However, this prototype did not use an EC sensor to detect the level of the nutrition solution in the water. The $\mathrm{pH}$ control and nutrient levels are regulated by a solenoid valve, actuated by a water pump, and the power is supplied by the PV module for 24 hours with varying tilt angles.

The EC wireless sensor supplied by Indonesia Electric Company (PLN) grid to monitor and control the concentration of the nutrient solution for hydroponic plant cultivation using two Nutrient Film Technique (NFT) tables based has been proposed in [2]. Each table was installed with monitoring and controlling of nutrition solution concentration devices which transmit the data to server through wireless sensor network. The results showed that the EC-meter sensor was able to read the density of the nutrient solution with a relative error percentage of $3.92 \%$. Node 2 was able to produce a faster threshold data transmission than node 1 with a delay for node 2 of 34.68 seconds and a delay for node 1 of 40.01 seconds. Node 1 was able to result in a better control accuracy of nutrient solution concentration at $96.12 \%$ compared to node 2 at $92.79 \%$. The weakness of this model was the performance of monitoring and control depending on temperature and the distance between the node and the coordinator. The higher the system temperature, so its performance also decreases. The farther the distance between the node and the coordinator, the loss of data transmission also will be greater.

The nutritional control, water temperature, water volume, environmental temperature, $\mathrm{pH}$, and humidity on the hydroponic system using the website has been implemented in [3]. The control of this prototype used the Node MCU esp 8266 v3 microcontroller. Data communication between hardware and software used wireless media. Temperature reading system water using the DS18B20 sensor, the water level using the HC-SR04 ultrasonic sensor, and the nutrition level measured by the nutrition solution sensor. This device was designed to be 
able to monitor and control the hydroponic system at nutrient temperatures at $23^{\circ} \mathrm{C}-27^{\circ} \mathrm{C}$, water height limits 5$10 \mathrm{~cm}$ and nutrient levels at the $600-800 \mathrm{ppm}$ limit. The weakness of this research was that it still operates using the website browser menu so that it requires internet access to monitor and control all parameters through this prototype model. The design of PV modules as a power source for DC pump and compared by AC pump to control water flow that supplies nutrients to NFT-type hydroponic plants has been proposed in [4]. This model showed that the use of solar panels and DC pumps to flow water to hydroponic plants is relatively more economical than an AC pump. However, the DC pump was not able to operate continuously, and to overcome this problem then the researchers proposed an AC pump using a DC$\mathrm{AC}$ inverter to drain water in the hydroponic system.

Control of $\mathrm{pH}$ and nutrition water levels in the hydroponic system of chili plants using Arduino Uno with microcontroller ATmega16 U2 has been observed in [5]. This prototype was capable of controlling a $\mathrm{pH}$ level between 6-6.5 and a nutrition water level between $6-8 \mathrm{~cm}$. The prototype of measuring and controlling water volume and water $\mathrm{pH}$ levels in hydroponic system using ultrasonic sensor and $\mathrm{pH}$ sensor with Arduino Uno have been proposed in [6]. The proposed system was capable of controlling water level between 10-14 $\mathrm{cm}$ and water $\mathrm{pH}$ between 5.5-7.5. The prototype of the EC control and water volume on hydroponic system using fuzzy logic has been observed in [7]. Fuzzy logic control using the EC sensor was able to control EC between $110-2000 \mu \mathrm{S} / \mathrm{cm}$ and generate good performance with an average error of $1.91 \%$. This model was also able to control the volume of water between $10-100 \mathrm{~mL}$ with an average error of $1.87 \%$. Nevertheless, the drawback of prototype model in $[2,3,5,6,7]$ was completely dependent on grid electricity so that if there is a supply disruption at the source side, the control and monitoring of hydroponic system will not be able to function normally.

This research will implement the prototype model to monitor and control the $\mathrm{pH}$ levels and nutrition plant supplied by a 100 watt-peak (Wp) standalone PV panelconnected battery on greenhouse hydroponic systems. The two sensors are connected to the Arduino Uno circuit as a relay control to drive four pumps, i.e. the water flow pump, EC pump, $\mathrm{pH}$ up pump, and $\mathrm{pH}$ down pump. The greenhouse function to control pests and environmental temperatures so that hydroponic plants can grow in an appropriate environment. The paper is arranged as follows. Chapter II presents the proposed research model, flow chart, PV module concept, greenhouse, Arduino Uno, relay circuit, $\mathrm{pH}$ sensor, EC sensor, liquid crystal display (LCD). Chapter III presents the results and discussion i.e. the design of monitoring and control systems for $\mathrm{pH}$ and EC levels, measurement and validating the PV and battery module voltages, measurement and validating $\mathrm{pH}$ sensor, measurement and validating EC sensor as well as analyzing the performance measurement result of $\mathrm{pH}$ sensor and EC sensor in greenhouse hydroponic plant systems. Finally, the paper is concluded in Chapter IV.

\section{Methodology}

\section{A. Research Method}

The monitoring and control system for $\mathrm{pH}$ and EC nutrition in the hydroponic greenhouse prototype consists of a combination of hardware and software. The hardware design consists of a PV module, battery (Lithium-Ion), $\mathrm{pH}$ sensor, and EC nutrition sensor combined with Arduino Uno software connected to four relays. These relays function to control the water flow pump, nutrient pump (EC), pH-up pump, and pH-down pump. The block diagram of the proposed model can be seen in Figure 1.

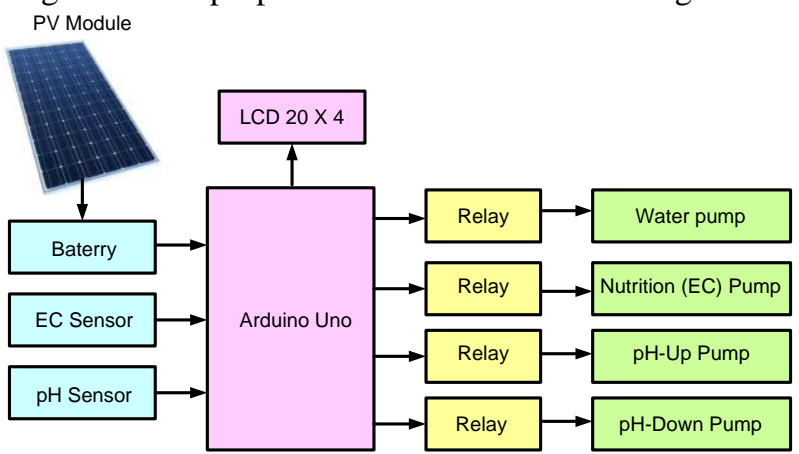

Figure 1. Proposed research model

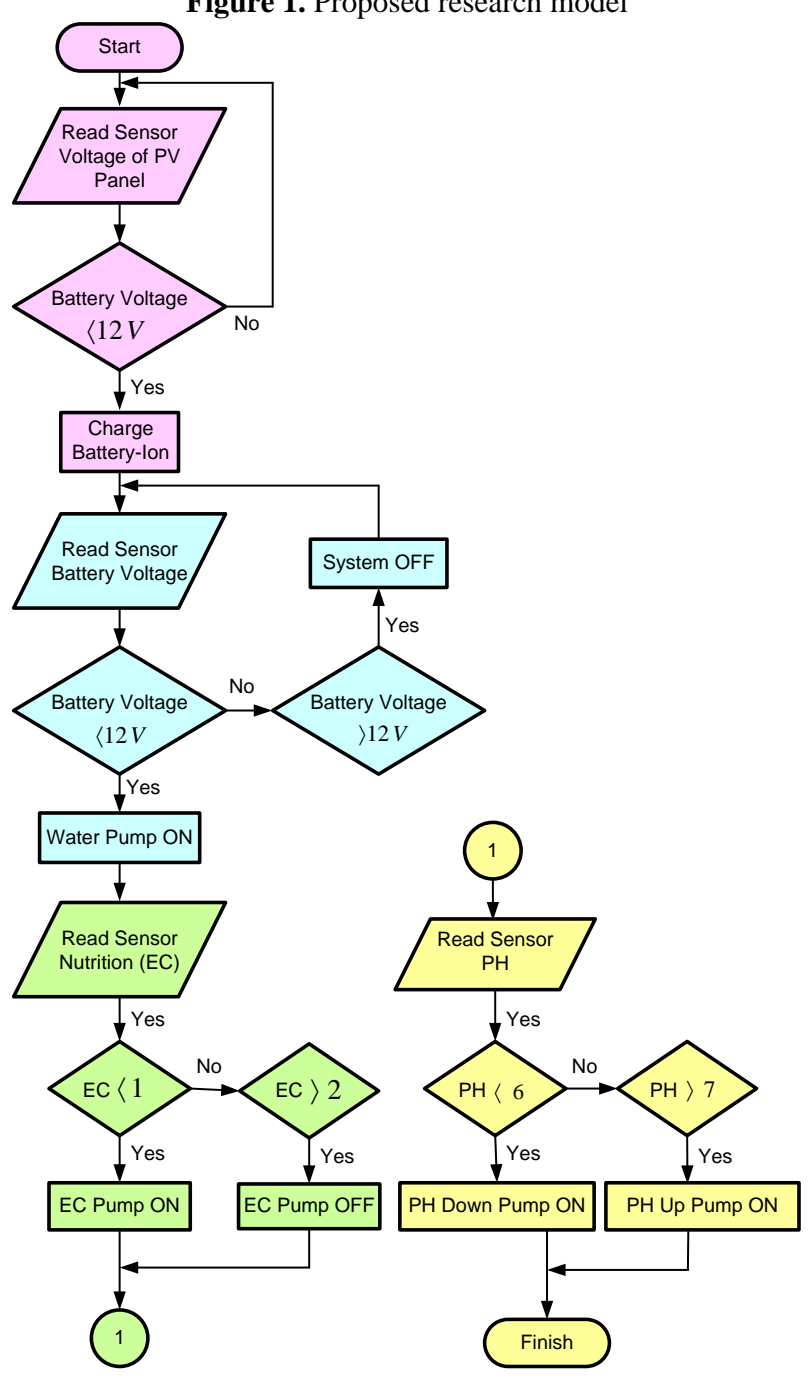

Figure 2. Research flowchart 
Figure 1 shows the proposed research model. This proposed model is called the monitoring system for $\mathrm{pH}$ and plant nutrition in a greenhouse hydroponic system using Arduino Uno. The $100 \mathrm{Wp}$ standalone photovoltaic (PV) module charges the battery (Lithium-Ion). After the battery is fully charged, the EC sensor and PH sensor will work. The Arduino Uno circuit with a $20 \times 4$ LCD display will then order four relays i.e. water flow pump, nutrient (EC) pump, $\mathrm{pH}$-up pump, and $\mathrm{pH}$-down pump to work to control the hydroponic system in a greenhouse based on the coding which has been written previously on ArduinoUno. Figure 2 shows the research flowchart. The research starts with the sensor reading the PV module output voltage. If the battery voltage is less than $12 \mathrm{~V}$, the PV power will charge previously the battery. Then, the battery voltage sensor will work logically if the battery voltage is less than $12 \mathrm{~V}$, then the water flow pump will work. Whereas if the battery voltage exceeds $12 \mathrm{~V}$, the system will shut down. After the water pump starts, the nutrition sensor (EC) will work logically if the EC is less than 1 then the EC pump will turn On and if the EC is greater than 2 then the EC pump will turn Off. Furthermore, the $\mathrm{pH}$ sensor works to monitor the $\mathrm{pH}$ level of the water. If the $\mathrm{pH}$ level is below 7 then the $\mathrm{PH}$ pump down will work $(\mathrm{On})$, conversely if the $\mathrm{pH}$ level is above 7 then the $\mathrm{pH}$ up pump will work (On).

\section{B. Modelling Photovoltaic}

The equivalent circuit of PV is shown in Figure 3. It consists of several PV cells which have external connections in series, parallel, or series-parallel [5].

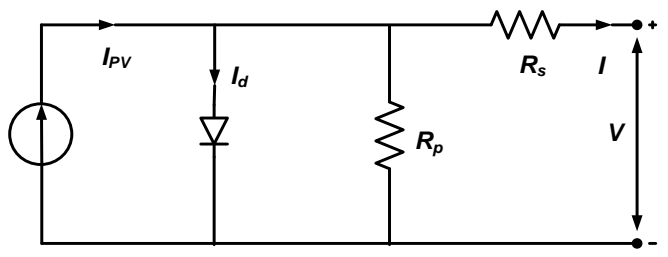

Figure 3. Equivalent circuit of PV panel

The V-I characteristic is shown in Eq. (1):

$I=I_{P V}-I_{o}\left[\exp \left(\frac{V+R_{S} I}{a V_{t}}\right)-1\right]-\frac{V+R_{S} I}{R_{P}}$

Where $I_{P V}$ is $\mathrm{PV}$ current, $I_{o}$ is saturated re-serve current, ' $\mathrm{a}$ ' is the ideal diode constant, $V=N_{S} K T q^{-1}$ is the thermal voltage, $N_{S}$ is a number of series cells, $q$ is the electron charge, $K$ is Boltzmann constant, $T$ is temperature pn junction, $R_{S}$ and $R_{P}$ are series and parallel resistance of solar panels. $I_{P V}$ has a linear relationship with light intensity and also temperature variation. $I_{O}$ is a dependent value on the temperature variation. Eq. (2) and Eq. (3) are the calculation of $I_{P V}$ and $I_{o}$ values:

$$
\begin{aligned}
& I_{P V}=\left(I_{P V, n}+K_{I} \Delta T\right) \frac{G}{G_{n}} \\
& I_{o}=\frac{I_{S C, n}+K_{I} \Delta T}{\exp \left(V_{O C, n}+K_{V} \Delta T\right) / a V_{t}-1}
\end{aligned}
$$

Where, $I_{P V, n}, I_{S C, n}$, and $V_{O C, n}$ are the photovoltaic current, short circuit current, and open-circuit voltage under standard conditions $\left(T_{n}=25^{0} \mathrm{C}\right.$ and $G_{n}=$ $1000 \mathrm{~W} / \mathrm{m}^{2}$ ), respectively. The $K_{I}$ value is the coefficient of short circuit current to temperature, $\Delta T=$ $T-T_{n}$ is temperature deviation from standard temperature, $G$ is the light intensity and $K_{V}$ is coefficient of open-circuit voltage ratio to temperature. Open circuit voltage, short circuit current, and voltage-current related to maximum power are three important values of $\mathrm{I}-\mathrm{V}$ characteristics of PV panel. These points are changed by variation in atmospheric conditions. By using Eq. (4) and Eq. (5) derived from the PV model equation, short-circuit current and open-circuit voltage can be calculated under different atmospheric conditions.

$$
\begin{aligned}
& I_{S C}=\left(I_{S C}+K_{I} \Delta T\right) \frac{G}{G_{n}} \\
& V_{O C}=\left(V_{O C}+K_{V} \Delta T\right)
\end{aligned}
$$

\section{Green House}

The greenhouse is a frame or corrugated building covered with a clear or translucent material that can transmit light optimally for production and protect plants from climatic conditions that are detrimental to plant growth. The cultivating of plants in a greenhouse has the advantage of a more controlled microenvironment and uniformity of production for each plant. The functions of a greenhouse include managing plant growth schedules, increasing production yields, minimizing pesticides, increasing production quality, assets, and performance, as well as a means of agro-tourism [6].

\section{Arduino Uno}

Arduino-Uno is an electronic board containing an ATMega328 microcontroller, which is a chip that functionally acts like a computer. This device is used to realize electronic circuits from simple to complex. LED control to robot control can be implemented using this relatively small board. In the health sector with the addition of certain components, this tool can be used to monitor the condition of patients in the hospital and control equipment at home [7]. Figure 4 shows the Arduino Uno model.

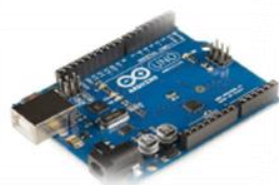

Figure 4. Arduino Uno model

\section{E. Relay Circuit}

The relay circuit is a link between the Arduino Uno circuit with the water flow pump, nutrient pump (EC), $\mathrm{pH}$ up pump, and $\mathrm{pH}$-down pump to work on controlling the greenhouse hydroponic system based on the coding previously programmed on Arduino-Nano. Figure 5 shows a relay circuit on the greenhouse hydroponic system. 


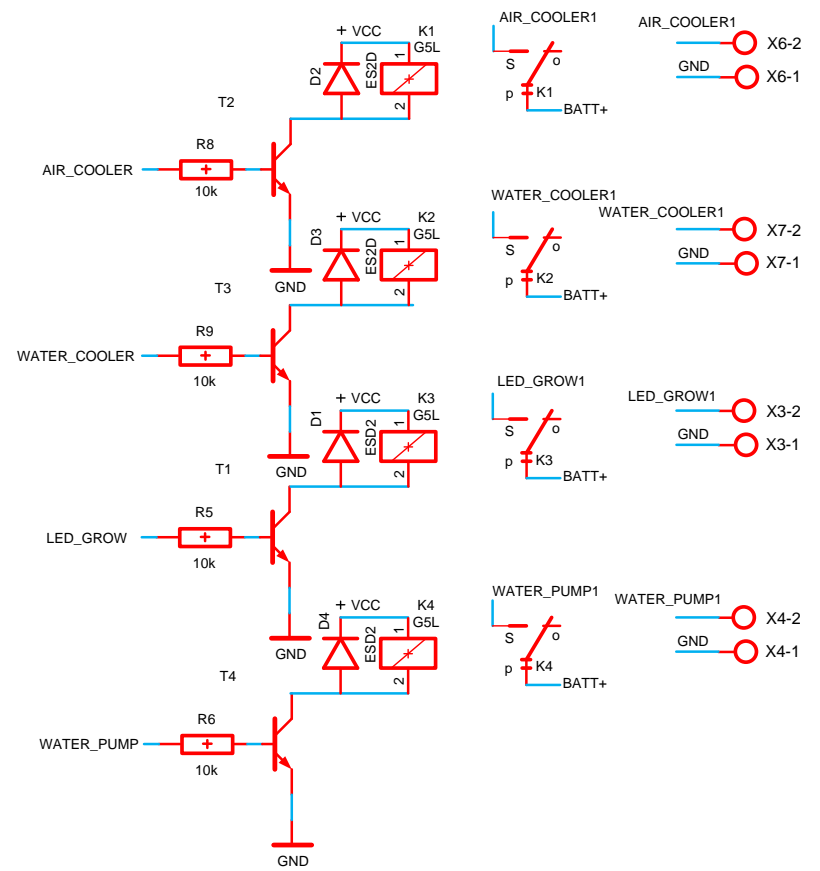

Figure 5. Relay circuit

\section{F. Sensor Electrical Conductivity}

The Electrical Conductivity (EC) sensor is used to measure the concentration of a solution for example hydroponic nutrient solution which is expressed in units of miliSiemens per centimeter $(\mathrm{mS} / \mathrm{cm})$. The EC-meter is an alternative measurement device to the Total Dissolved Solids (TDS)-meter to measure the concentration of a hydroponic nutrient solution expressed in units of parts per million (ppm) [8]. The EC value affects the rate of nutrition absorption by plants, the greater the EC value, the faster the absorption of nutrition by plants and vice versa if the EC value is smaller, the absorption of nutrition will be slow [9]. The series of EC sensors installed in the greenhouse hydroponic system is connected to the Arduino-Uno, using the IDE software and libraries in the Arduino Uno. Figure 6 shows the EC sensor circuit.

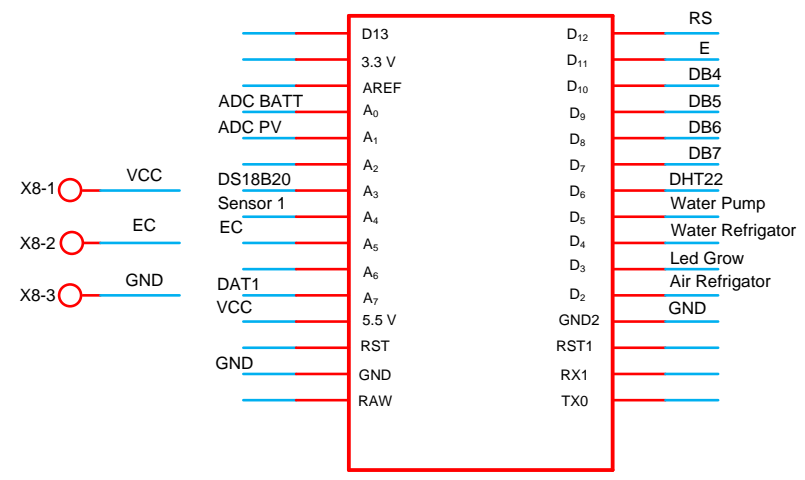

Figure 6. EC sensor circuit

\section{G. Sensor $p H$}

The $\mathrm{pH}$ sensor is an instrument for measuring the concentration of hydrogen in a solution. The $\mathrm{pH}$ sensors for water and for soil need to be calibrated periodically so that the accuracy of the measurement is guaranteed. The series of $\mathrm{pH}$ sensors installed in the greenhouse hydroponic system is connected to the Arduino-Uno, using the IDE software and libraries in the Arduino Uno. The $\mathrm{pH}$ sensor circuit is shown in Figure 7.

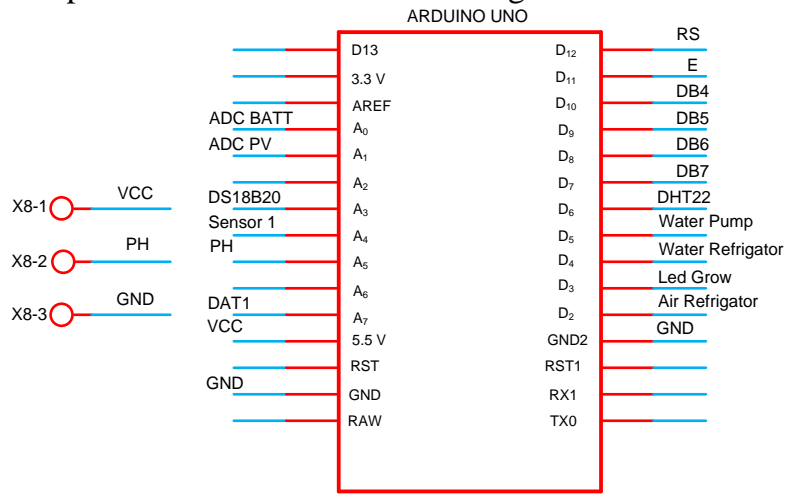

Figure 7. The $\mathrm{pH}$ sensor circuit

\section{H. Liquid Crystal Display}

Liquid Crystal Display (LCD) is a type of display media that uses liquid crystals as the main display. LCD has been used in various fields, for example in electronic devices, such as televisions, calculators, or computer screens. The LCD circuit that is installed with a greenhouse hydroponic is connected to the Arduino-Uno, using the IDE software and libraries in the Arduino Uno. Figure 8 shows the LCD circuit.

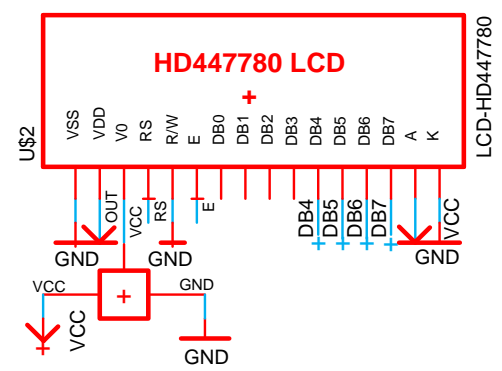

Figure 8. LCD circuit

\section{RESUlTS AND DISCUSSION}

Figure 9 shows the implementation of a monitoring system for $\mathrm{pH}$ and plant nutrition in a greenhouse hydroponic system using Arduino Uno. Figure 9.a shows (1) Arduino-Uno Controller, (2) Solenoid Valve, (3) Hydroponic Plant, (4) Nutrition EC, (5) pH-up, and (6) $\mathrm{pH}$-down. Figure 9.b. shows nutrient water and sensors. Figure 9.c shows the PV module connected to a battery (Lithium-Ion). The working mechanism of this prototype is started by the sensors read the output voltage of the PV module. If the battery voltage is less than $12 \mathrm{~V}$, the PV output power will charge the battery. In this condition, the battery voltage sensor will work and the water pump will also work. After the water pump starts then the EC sensor also works, with logic if the EC level is greater than 1 then the EC pump will turn on and if the EC level is less than 2 then the EC pump will shut down. Furthermore, the $\mathrm{pH}$ sensor works to monitor the $\mathrm{PH}$ level of the water. If the $\mathrm{PH}$ level is below 7 then the PH-down pump will work (On), otherwise if the $\mathrm{pH}$ level is above 7 then the $\mathrm{pH}$-up pump will work (On). To obtain better monitoring and control system performance, a number of validation 
measurements are carried out i.e. PV voltage, battery voltage, EC sensor, and $\mathrm{pH}$ sensor.

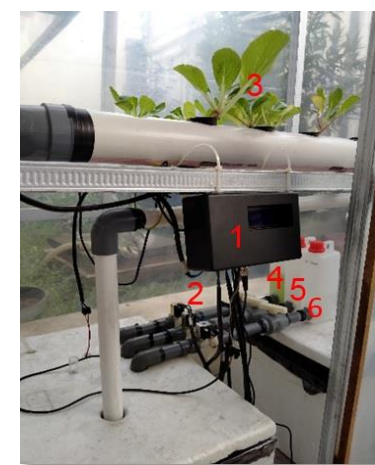

(a)

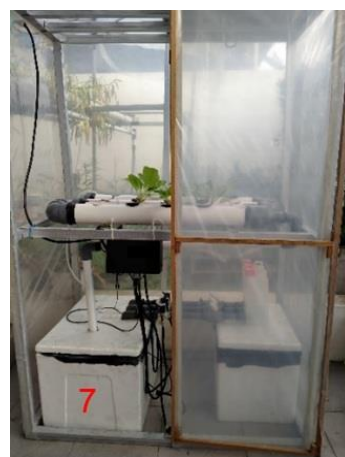

(b)

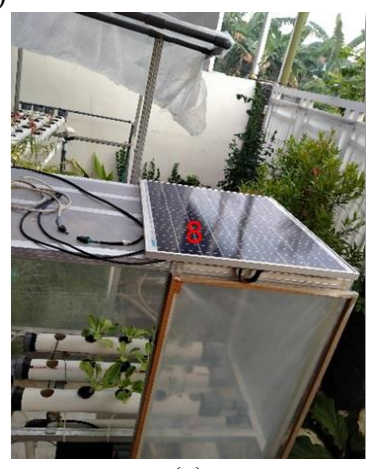

(c)

Figure 9. Implementation of a monitoring system for $\mathrm{pH}$ and plant nutrition in a greenhouse hydroponic system

Table 1. Measurement of PV voltage

\begin{tabular}{cccc}
\hline No. & $\begin{array}{c}\text { Volt Meter } \\
(\mathbf{V})\end{array}$ & $\begin{array}{c}\text { PV Voltage } \\
\text { Sensor }(\mathbf{V})\end{array}$ & Error $(\%)$ \\
\hline 1 & 5.00 & 5.07 & 1.400 \\
\hline 2 & 7.00 & 7.10 & 1.429 \\
\hline 3 & 9.00 & 9.09 & 1.000 \\
\hline 4 & 12.00 & 12.08 & 0.667 \\
\hline
\end{tabular}

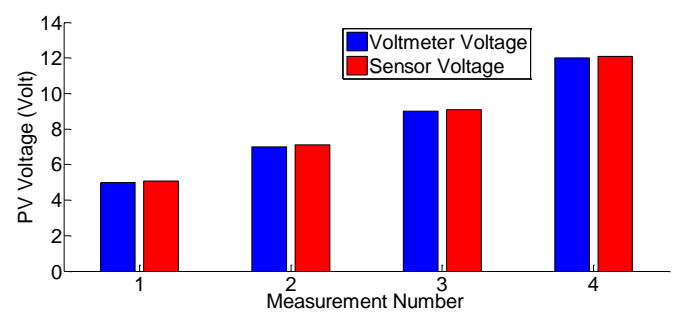

Figure 10. Measurement of PV voltage

Table 1 and Figure 10 show the PV voltage measurement using a voltmeter and a PV voltage sensor. The first measurement with a voltmeter produces a PV voltage of $5 \mathrm{~V}$, while the measurement uses a sensor as $5.07 \mathrm{~V}$. The fourth measurement with a voltmeter produces a PV voltage of $12 \mathrm{~V}$, while the measurement uses a sensor as $12.08 \mathrm{~V}$. The four measurement results show that the PV voltage sensor produces a measurement accuracy close to the same compared to measurements using a voltmeter with a maximum error of $1.429 \%$ or already below $5 \%$.

Table 2 and Figure 11 show the battery voltage measurement using a voltmeter and a battery voltage sensor. The first measurement with a voltmeter produces a PV voltage of $5 \mathrm{~V}$, while the measurement using a sensor resulting of $5.10 \mathrm{~V}$. The fourth measurement with a voltmeter produces a PV voltage of $12 \mathrm{~V}$, while the measurement using a sensor resulting of $12.07 \mathrm{~V}$.

Table 2. Measurement of battery voltage

\begin{tabular}{cccc} 
No. & $\begin{array}{c}\text { Volt Meter } \\
(\mathbf{V})\end{array}$ & $\begin{array}{c}\text { Battery Voltage } \\
\text { Sensor }(\mathbf{V})\end{array}$ & Error $(\boldsymbol{\%})$ \\
\hline 1 & 5.00 & 5.10 & 2.000 \\
\hline 2 & 7.00 & 7.06 & 0.857 \\
\hline 3 & 9.00 & 9.09 & 1.000 \\
\hline 4 & 12.00 & 12.07 & 0.583 \\
\hline
\end{tabular}

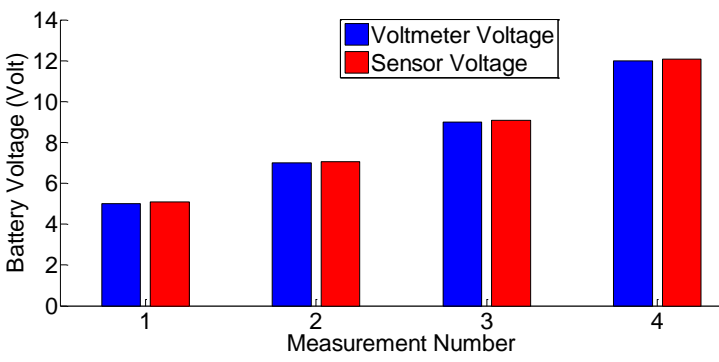

Figure 11. Measurement of battery voltage

The four measurements on Table 2 and Figure 11 show that the battery voltage sensor produces a measurement accuracy close to the same compared to measurements using a battery with a maximum error of $2 \%$ or already below $5 \%$. PH sensor measurements are carried out to ensure the sensor can run properly because it can affect $\mathrm{pH}$ measurements when monitoring equipment is applied to hydroponic plants in greenhouse. Figure 12 shows $\mathrm{pH}$ measurements using a digital $\mathrm{pH}$ meter. Figure 13 shows $\mathrm{pH}$ measurements using a $\mathrm{pH}$ sensor. Table 3 shows the measurements of water $\mathrm{pH}$ using a digital $\mathrm{pH}$ meter and $\mathrm{pH}$ sensor. Figure 13 shows the comparison of the $\mathrm{pH}$ of the water using a digitalmeter and sensor.

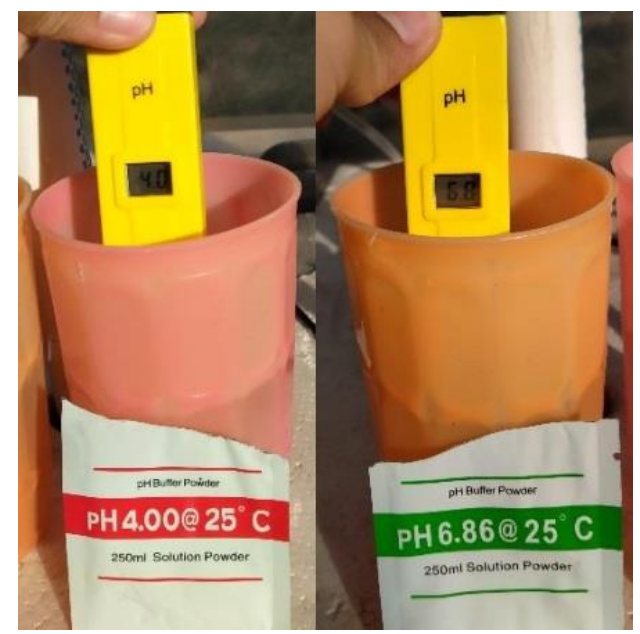

Figure 12. $\mathrm{pH}$ measurement using digital-meter

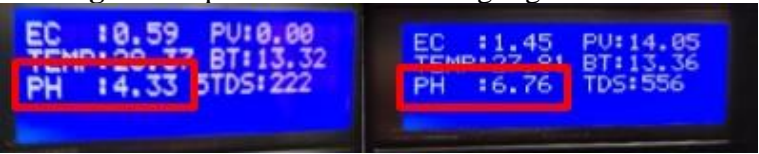

Figure 13. $\mathrm{pH}$ measurement using sensor 
Table 3 Measurements of water $\mathrm{pH}$ using a digital $\mathrm{pH}$ meter and $\mathrm{pH}$ sensor

\begin{tabular}{clcccc}
\hline No. & $\begin{array}{l}\text { PH } \\
\text { Water }\end{array}$ & $\begin{array}{l}\text { Digital PH } \\
\text { meter }\end{array}$ & $\begin{array}{l}\text { Error } \\
(\boldsymbol{\%})\end{array}$ & $\begin{array}{l}\text { Sensor } \\
\text { PH }\end{array}$ & $\begin{array}{l}\text { Error } \\
(\boldsymbol{\%})\end{array}$ \\
\hline 1 & 4.00 & 4.0 & 0 & 4.33 & 8.250 \\
\hline 2 & 6.86 & 6.8 & 0.875 & 6.76 & 1.458 \\
\hline
\end{tabular}

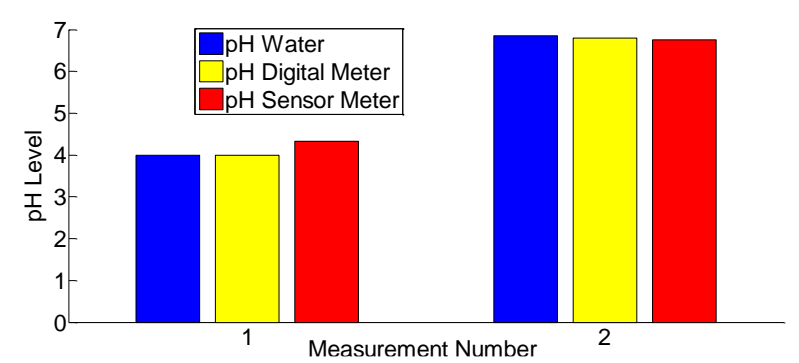

Figure 14. Comparison of the $\mathrm{pH}$ water using a digital-meter and sensor

Table 3 and Figure 14 show that on first measurement the $\mathrm{pH}$ value of water is 4 , read by digital $\mathrm{pH}$ meter and $\mathrm{pH}$ sensor of 4.0 and 4.33 , respectively. Otherwise, on the second measurement shows that the $\mathrm{pH}$ value of the water is 6.86 , which is read by a digital $\mathrm{pH}$ meter and a pH sensor of 6.8 and 6.76, respectively. Table 3 shows that measurements using a digital $\mathrm{pH}$ meter and a $\mathrm{pH}$ sensor are able to give close to the same results. The measurement results of digital $\mathrm{pH}$ meter with water $\mathrm{pH}$ below 6 is accurate because they produce an error of $0 \%$. Then, the measurement of $\mathrm{pH}$ digital meter with water $\mathrm{pH}$ values between 6-7 is relatively accurate because it produces an error of $0.875 \%$ or is already below $5 \%$.

Table 3 and Figure 14 also show that on the first measurement results of $\mathrm{pH}$ sensors with water $\mathrm{pH}$ below 6 are still inaccurate because they produce an error of $8.250 \%$. However, on the second measurement of $\mathrm{pH}$ sensors with water $\mathrm{pH}$ values between 6-7 is relatively accurate because it produces an error of $1.458 \%$ or is already below $5 \%$. EC sensor measurements are carried out to ensure the nutrition sensor is functioning properly, because this indicator will affect the EC measurement of the water when the monitoring system is running. Table 4 shows the measurement of nutrition levels using the TDS sensor and the EC sensor.

Table 4. Nutrition measurement using TDS and EC sensors

\begin{tabular}{cccc}
\hline No. & $\begin{array}{c}\text { Digital TDS } \\
(\mathbf{p p m})\end{array}$ & $\begin{array}{c}\text { Sensor TDS } \\
(\mathbf{p p m})\end{array}$ & $\begin{array}{c}\text { Sensor EC } \\
(\mathbf{m S} / \mathbf{c m})\end{array}$ \\
\hline 1 & 450 & 458 & 1.23 \\
\hline 2 & 540 & 542 & 1.45 \\
\hline 3 & 760 & 765 & 2.05 \\
\hline 4 & 880 & 882 & 2.30 \\
\hline
\end{tabular}

The performance measurement of the $\mathrm{pH}$ monitoring system is carried out to ensure that the $\mathrm{pH}$ of the water can be controlled to a degree of acidity between 6-7. This range of values is needed to keep hydroponic plant growth relatively stable. The measurements are made on a hydroponic plant monitoring system, using a relay that functions to run the $\mathrm{pH}$ pump motor. The function of $\mathrm{pH}$ -
Up and $\mathrm{pH}$-Down is to keep the $\mathrm{pH}$ of hydroponic plant water at the level of 6-7. Table 5 shows the performance measurements of the $\mathrm{pH}$ sensor. Figure 15 shows the measurement of $\mathrm{pH}-\mathrm{Up}$ performance at 08.00 and 14.00 hours.

Table 5. Performance measurement using $\mathrm{pH}$ sensor

\begin{tabular}{|c|c|c|c|}
\hline Hours & Sensor pH & pH-Up & pH-Down \\
\hline 08.00 & 4.33 & On & Off \\
\hline 10.00 & 6.45 & Off & Off \\
\hline 12.00 & 6.76 & Off & Off \\
\hline 14.00 & 7.32 & Off & On \\
\hline 16.00 & 6.47 & Off & Off \\
\hline \multirow{2}{*}{\multicolumn{2}{|c|}{ 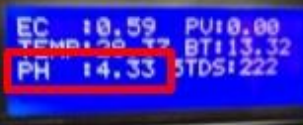 }} & $\begin{array}{l}\text { EC : }: 1.28 \\
\text { PH : }: 7.33\end{array}$ & \multirow[t]{2}{*}{$\begin{array}{l}\text { PU: } 14.16 \\
\text { II: } 15.44 \\
\text { DS: } 480\end{array}$} \\
\hline & & & \\
\hline
\end{tabular}

Figure 15. Performance measurement of pH-Up at 08.00 and 14.00 hours

Table 5 and Figure 15 show that at 08.00 the $\mathrm{pH}$ level is below 6 so that the pH-Up sensor is on. In this condition, the solenoid valve will open to drain $\mathrm{pH}-\mathrm{Up}$ water so that the $\mathrm{pH}$ value rises to above 6 . On the other hand, at 10.00, 12.00, 14.00, and 16.00 the $\mathrm{pH}$ level is above 6 so that the $\mathrm{pH}-\mathrm{Up}$ sensor is in the Off status. Table 5 and Figure 15 also show that at 14.00 hours the $\mathrm{pH}$ level is above 7 so that the $\mathrm{pH}$-down sensor is On. In this condition, the solenoid valve will open to drain $\mathrm{pH}$-down water to lower the $\mathrm{pH}$ value to below 7. On the other hand, at $08.00,10.00,12.00$, and 16.00 hours the $\mathrm{pH}$ level are already below 7 so that the pH-down sensor is automatically in the Off status.

The performance measurement of EC is carried out to ensure that the water nutrition concentration can be controlled within a value range of $1-2 \mathrm{mS} / \mathrm{cm}$. The EC control is needed to keep hydroponic plant growth relatively stable. The measurements are made on the hydroponic plant monitoring system, using a relay that functions to run the EC pump motor. Table 6 shows the performance measurements using an EC sensor. Figure 15 shows the measurement of EC at 08.00 and 16.00 hours.

Table 6. Performance measurements using EC sensor

\begin{tabular}{ccc}
\hline Hours & Sensor EC & EC-Up \\
\hline 08.00 & 0.59 & On \\
\hline 10.00 & 1.45 & Off \\
\hline 12.00 & 1.28 & Off \\
\hline 14.00 & 1.32 & Off \\
\hline 16.00 & 1.30 & Off \\
\hline
\end{tabular}

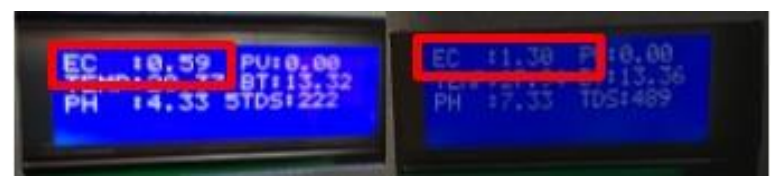

Figure 16. Performance measurement of EC sensor at 08.00 and 16.00 hours 
Table 6 and Figure 16 show that at 08.00 hours the level of EC nutrition is still below 1 so that the EC-Up sensor is On. In this condition, the solenoid valve will open to drain EC water and raise the $\mathrm{pH}$ level to above 1.
On the other hand, at 10.00, 12.00, 14,000, and 16.00 the EC nutrient level is already above 1 so that the EC-Up sensor is automatically in the Off status.

Table 7. Comparison between prototype hydroponic greenhouse-Arduino-Uno-standalone PV (proposed study) than previous studies

\begin{tabular}{|c|c|c|c|c|c|c|c|c|c|}
\hline Authors & $\begin{array}{c}\text { Methods/ } \\
\text { Devices }\end{array}$ & $\begin{array}{c}\text { Ph } \\
\text { Level }\end{array}$ & $\begin{array}{c}\text { EC } \\
\text { Level }\end{array}$ & $\begin{array}{c}\text { High/ } \\
\text { Vol. Level }\end{array}$ & $\begin{array}{l}\text { Temp. } \\
\text { Level }\end{array}$ & $\begin{array}{c}\text { Monitored } \\
\text { by }\end{array}$ & $\begin{array}{l}\text { Power } \\
\text { Supply }\end{array}$ & $\begin{array}{l}\text { Real } \\
\text { Time }\end{array}$ & $\begin{array}{c}\text { Green- } \\
\text { house }\end{array}$ \\
\hline $\begin{array}{c}\text { Fitria } \\
\text { Hidayanti, } \\
\text { et.al. [1] }\end{array}$ & Arduino Uno & $6-7$ & NA & $18-20 \mathrm{~cm}$ & NA & $\begin{array}{c}\text { LCD } \\
\text { Display }\end{array}$ & $\begin{array}{l}\text { Standalone } \\
\text { PV-Battery }\end{array}$ & Yes & No \\
\hline $\begin{array}{c}\text { Helmy, et.al. } \\
{[2]}\end{array}$ & $\begin{array}{c}\text { Nutrient Film } \\
\text { Technique }\end{array}$ & NA & $\begin{array}{l}1.4 \mathrm{mS} \text { or } \\
700 \mathrm{ppm}\end{array}$ & NA & NA & Website & Grid PLN & No & No \\
\hline $\begin{array}{l}\text { Yuga Had- } \\
\text { fridar Putra, } \\
\text { et. al [3] }\end{array}$ & $\begin{array}{c}\text { Microcontroller } \\
\text { NodeMCU } \\
\text { esp8266 v3 } \\
\end{array}$ & NA & $\begin{array}{l}\text { 600-800 } \\
\text { ppm }\end{array}$ & $5-10 \mathrm{~cm}$ & $\begin{array}{c}23^{0}- \\
27^{0} \mathrm{C}\end{array}$ & Website & Grid PLN & No & No \\
\hline $\begin{array}{c}\text { David } \\
\text { Setiawan, et. } \\
\text { al. [4] }\end{array}$ & $\begin{array}{l}\text { Nutrient Film } \\
\text { Technique }\end{array}$ & NA & NA & NA & NA & NA & $\begin{array}{l}\text { Standalone } \\
\text { PV-Battery }\end{array}$ & No & No \\
\hline $\begin{array}{l}\text { Muhammad } \\
\text { Tirto Utomo, } \\
\text { et.al [5] }\end{array}$ & $\begin{array}{l}\text { Arduino Uno } \\
\text { using Micro- } \\
\text { controller } \\
\text { ATMega16 } \\
\text { U2 }\end{array}$ & $6-6.5$ & NA & $6-8 \mathrm{~cm}$ & NA & $\begin{array}{c}\text { LCD } \\
\text { Display }\end{array}$ & Grid PLN & Yes & No \\
\hline $\begin{array}{l}\text { Muhammad } \\
\text { Fakhruzzaini, } \\
\text { et. al. [6] }\end{array}$ & $\begin{array}{c}\text { Arduino Uno } \\
\text { using Micro- } \\
\text { controller } \\
\text { ATMega328 }\end{array}$ & $\begin{array}{l}5.5- \\
7.5\end{array}$ & NA & $10-14 \mathrm{~cm}$ & NA & $\begin{array}{c}\text { LCD } 16 \times 2 \\
\text { Display }\end{array}$ & Grid PLN & Yes & No \\
\hline $\begin{array}{c}\text { Ahmad Rifai, } \\
\text { et.al. [7] }\end{array}$ & $\begin{array}{c}\text { Arduino Uno } \\
\text { using Fuzzy } \\
\text { Logic } \\
\text { Controller }\end{array}$ & NA & $\begin{array}{c}110-2000 \\
\mu \mathrm{S} / \mathrm{cm}\end{array}$ & $10-100 \mathrm{~mL}$ & NA & $\begin{array}{c}\text { LCD } 16 \times 2 \\
\text { Display }\end{array}$ & Grid PLN & Yes & No \\
\hline $\begin{array}{l}\text { Proposed } \\
\text { Study }\end{array}$ & $\begin{array}{c}\text { Arduino Uno } \\
\text { using Micro- } \\
\text { controller } \\
\text { ATMega328 }\end{array}$ & 6-7 & $\begin{array}{c}1-2 \\
\mathrm{mS} / \mathrm{cm}\end{array}$ & NA & NA & $\begin{array}{c}\text { LCD } \\
20 \times 4 \\
\text { Display }\end{array}$ & $\begin{array}{l}\text { Standalone } \\
\text { PV-Battery }\end{array}$ & Yes & Yes \\
\hline
\end{tabular}

Note: $\mathrm{NA}=$ not available

Table 7 shows the prototype validation of the proposed hydroponic plant monitoring and control model compared to the previous seven prototypes. The parameters observed were $\mathrm{pH}$ level, EC level, high or volume water level, temperature level, measurement monitoring, hydroponic power supply, real-time measurement simulation, and the use of a greenhouse in a hydroponic system. In [1], Fitria Hidayanti, et. al have proposed Arduino Uno be supplied by Standalone PVBattery to control the $\mathrm{pH}$ level and nutrient water level which their values monitored in real-time using an LCD. This prototype was able to control the $\mathrm{pH}$ level between 6-8 and the nutrition water level between $18-20 \mathrm{~cm}$. In [2], Helmy, et. al. have proposed a Nutrient Film Technique supplied by the Indonesia Electric Company (PLN) grid to control the EC level of $1.4 \mathrm{~ms}$ or $700 \mathrm{ppm}$ whose value was monitored wirelessly by the website. In [3], Yuga Hadfridar Putra, et.al have proposed the Arduino Uno be supplied by the PLN Grid to control the EC level, nutrition water high level, temperature, and its value to be monitored wirelessly by the website. This prototype was able to control the EC level between 600-800 ppm, a high level between $5-10 \mathrm{~cm}$, and a temperature level of $23^{\circ}-27^{0}$ C. The weakness of the prototype model in $[2,3]$ was that it still used a database so that the measurement of performance parameters on both hydroponic systems still has a time delay. In [4], David Setiawan et.al have proposed Nutrient Film Technique to be supplied by Standalone PV-Battery. The weakness of this prototype only regulated the power supply from the PV-battery to the hydroponic system prototype and was still unable to control and monitor system performance parameters.

In [5], Muhammad Tirto Utomo, et. al proposed Arduino Uno using Microcontroller ATMega16 U2 be supplied by the PLN Grid to control the $\mathrm{pH}$ level, nutrient water level, and its value was able to be monitored in realtime using an LCD. This prototype was able to control the $\mathrm{pH}$ level between 6-6.5 and the nutrition water level between 6-8 cm. In [6], Muhammad Fakhruzzaini, et. al have proposed Arduino Uno using the ATMega328 Micro-controller supplied by the PLN grid to control the $\mathrm{pH}$ level between 5.5-6.5 and the nutrition water level between $10-14 \mathrm{~cm}$, and the value is monitored in real-time with a $16 \times 2$ LCD. In [7], Ahmad Rifai, et.al have proposed Arduino Uno using the Fuzzy Logic Controller supplied by the PLN Grid to control the EC level and nutrition water level and its value to be monitored realtime using a $16 \times 2 \mathrm{LCD}$. This prototype was able to control EC levels between 110-2000 $\mu \mathrm{S} / \mathrm{cm}$ and nutrition water volume between $10-100 \mathrm{~mL}$. In this study, the authors propose Arduino Uno using a Microcontroller ATMega328 supplied by Standalone PV-Batteries to 
control $\mathrm{pH}$ and EC levels and monitor their values in realtime using a $20 \times 4 \mathrm{LCD}$. This prototype was able to control pH levels between 6-7 and EC levels between 1-2 $\mathrm{mS} / \mathrm{cm}$. The advantage of the proposed model is that the character of the LCD is wider so that besides being able to display $\mathrm{pH}$ and EC parameter measurements, it is also able to display data on temperature, time, PV voltage, battery voltage, and TDS value. The proposed hydroponic system prototype also has been in the form of a greenhouse to keep the plant growth process taking place in the desired environmental conditions and at the same time preventing attacks from pests and diseases.

\section{CONCLUSION}

The prototype model to monitor and control the $\mathrm{pH}$ levels and EC nutrition plant supplied by a standalone PV module-connected battery on greenhouse hydroponic systems has been implemented. The two sensors are connected to the Arduino Uno and relay control to drive four pumps, i.e. the water flow pump, EC pump, $\mathrm{pH}$ up pump, and $\mathrm{pH}$ down pump. The prototype model is able to monitor and control the $\mathrm{pH}$ of hydroponic plant water at the level between 6-7 using $\mathrm{pH}$-up and $\mathrm{pH}$-down sensor. This model is also able to monitor and control nutrition plant water over $1 \mathrm{mS} / \mathrm{cm}$ using EC sensor. The advantage of the proposed model is that the character of the $20 \times 4 \mathrm{LCD}$ is wider so that besides being able to display $\mathrm{pH}$ and EC parameter measurements, it is also able to display data on temperature, time, PV voltage, battery voltage, and TDS value. The proposed hydroponic prototype system also has been in the form of a greenhouse to keep the plant growth process taking place in the desired environmental conditions and at the same time preventing attacks from pests and diseases. The implementation of the EC sensor is only able to control the EC value if the value is less than $1 \mathrm{mS} / \mathrm{cm}$. On the other hand, optimal plant growth in a hydroponic greenhouse system requires controlled EC values between 1-2 $\mathrm{mS} / \mathrm{cm}$. The use of an EC-down sensor to control the EC value so as not to exceed the $2 \mathrm{mS} / \mathrm{cm}$ value is proposed as future work to overcome this problem.

\section{ACKNOWLEDGEMENT}

The authors would like to acknowledge to Institutions of Research and Community Service Universitas Bhayangkara Surabaya for funding to this research.

\section{REFERENCES}

[1] F. Hidayanti, M. Innah, and F. Rahmah, "Implementasi Panel Surya Sebagai Sumber Energi pada Sistem Kendali $\mathrm{Ph}$ dan Level Larutan Nutrisi Tanaman Hidroponik", Jurnal Otomasi, Kontrol, dan Instrumentasi, vol. 11, no. 2, pp. 95-107, 2019.

[2] Helmy, A. Rahmawati, S. Ramadhan, T. A. Setyawan, and A. Nursyahid, "Pemantauan dan Pengendalian Kepekatan Larutan Nutrisi Hidroponik Berbasis Jaringan Sensor Nirkabel," Jurnal Nasional Teknik Elektro dan Teknologi Informasi, vol. 7, no. 4, pp. 391-396, November 2018.
[3] Y.H. Putra, D. Triyanto, and Suhardi, "Sistem Pemantauan dan Pengendalian Nutrisi, Suhu, dan Tinggi Air pada Pertanian Hitroponik Berbasis Website", Jurnal Coding, Sistem Komputer Untan, vol. 6, no. 3, pp. 128-138, 2018.

[4] D. Setiawan, H. Eteruddin, and L. Siswati, "Sistem Pembangkit Listrik Tenaga Surya untuk Tanaman Hidroponik", Jurnal Teknik, vol. 14, no. 2, pp 208-215, Oktober 2020.

[5] M.T. Utomo, V.V.R..Repi, and F. Hidayanti, "Pengatur Kadar Asam Nutrisi (pH) dan Level Ketinggian Air Nutrisi pada Sistem Hidroponik Cabai," Jurnal Ilmiah GIGA, vol. 21, no. 1, pp. 5-14, June 2018.

[6] M. Fakhruzzaini and H. Aprilianto, "Sistem Otomatisasi Pengontrolan Volume Dan PH Air Pada Hidroponik", JUTISI, vol. 6, no. 1, pp. 1311-1448, April 2017.

[7] A. Rifai, S. Sembiring, A. Farissi, and D.G.K. Karo, "Perancangan Sistem Pengatur Electrical Conductivity (EC) Air Menggunakan Kendali Logika Fuzzy", Jurnal Informatik, vol. 16, no. 1, pp. 47-58, April 2020.

[8] A. Amirullah, A. Adiananda. O. Penangsang, and A. Soeprijanto, "Load Active Power Transfer Enhancement Using UPQC-PV-BES System with Fuzzy Logic Controller," International Journal of Intelligent Engineering and Systems, vol. 13, no. 2, pp. 329-349, 2020.

[9] P.V. Nelson, "Greenhouse Operation and Management $7^{\text {th }}$ Edition," Pearson Education, Inc., Upper Saddle River, New Jersey, 2012.

[10] A. Kadir, "Panduan Praktis Mempelajari Aplikasi Mikrokontroler dan Pemrogramannya Menggunakan Arduino," Andi Publisher, ISBN: 9789792940176, January 2013.

[11] A. Wijayani and W. Widodo, "Usaha Meningkatkan Kualitas Beberapa Varietas Tomat dengan Sistem Budidaya Hidroponik," Ilmu Pertanian, vol. 12, no.1, pp. 77-83, 2005.

[12] S. K. Sudarmodjo and Y. Sutiyoso, "Hidroponik Skala Rumah Tangga," Agro Media Pustaka Publisher, ISBN: 979-3084-79-0, 2005. 